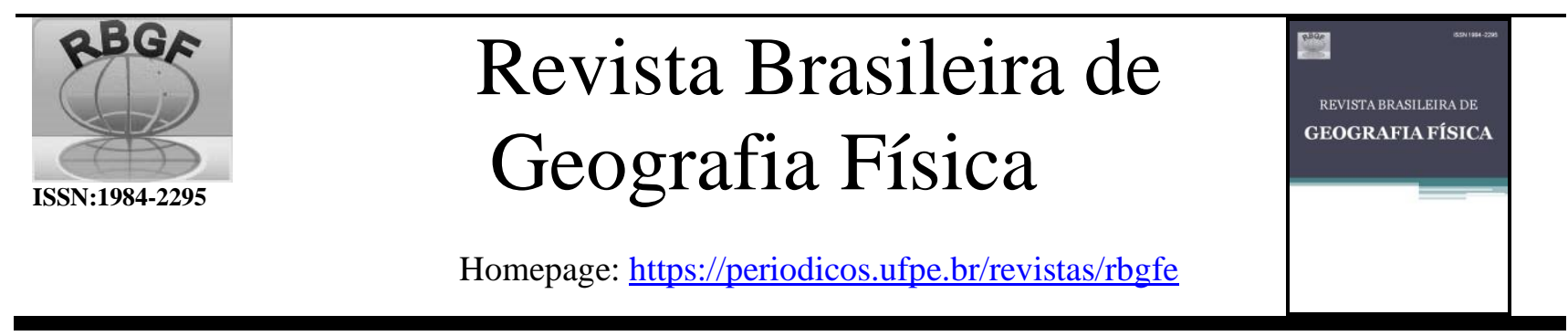

\title{
Diagnóstico físico, socioeconômico e socioambiental do território da área de proteção ambiental (APA) do Rio Maior - Santa Catarina - Brasil
}

Thaise Sutil, e-mail: thaise.sutil@gmail.com Laboratório de Planejamento e Gestão Territorial (LabPGT) Universidade do Extremo Sul Catarinense Nilzo Ivo Ladwig, e-mail: ladwig@unesc.net Professor do Programa de PósGraduação em Ciências Ambientais da Universidade do Extremo Sul Catarinense Álvaro José Back e-mail: ajb@unesc.net Professor do Programa de Pós-Graduação em Ciências Ambientais da Universidade do Extremo Sul Catarinense Danrlei De Conto e-mail: danrleideconto@ hotmail.com Laboratório de Planejamento e Gestão Territorial (LabPGT) - Universidade do Extremo Sul Catarinense

Artigo recebido em 27/03/2019 e aceito em 24/10/2019

\begin{abstract}
R E S U M O
Com o intuito de conservar os recursos hídricos e a vegetação existente na bacia hidrográfica do rio Maior, foi criada a Área de Preservação Ambiental (APA) do Rio Maior, por meio do projeto de Lei Municipal n. 1.665/1998. No entanto, além da sua criação definida por lei, é necessário o seu gerenciamento, o que não ocorreu na APA do Rio Maior. Passados vinte anos da criação, ainda não foi instituído o Conselho Consultivo e, consequentemente, não foi elaborado o plano de manejo. Diante desse contexto envolvendo a APA do Rio Maior, desenvolveu-se estudo que tem como objetivo caracterizar os aspectos físicos, socioeconômico e socioambiental do território onde está inserida a APA. Para alcançar o objetivo proposto, utilizou-se de pesquisa documental, pesquisa bibliográfica e geoprocessamento. Como resultado do estudo, foram gerados produtos cartográficos da geologia, dos recursos minerais, da geomorfologia, da declividade, da altimetria, da pedologia, do clima, da hidrografia, da vegetação, dos aspectos históricos, da população residente nas comunidades inseridas dentro do território da APA, da estrutura fundiária, das atividades agropecuárias, das atividades comerciais, industriais e de serviços, dos aspectos relativos ao uso e cobertura da terra e os impactos socioambientais. Os mapas temáticos associativos e específicos produzidos são informações que poderão promover as análises qualitativas e quantitativas para fins de simulações e tomadas de decisão no contexto da elaboração do plano de manejo.
\end{abstract}

Palavras-chaves: Unidade de Conservação (UC). Geoprocessamento. Análise ambiental.

\section{Physical, socioeconomic and socio-environmental diagnosis of the territory of the environmental protection area (APA) of Rio Maior - Santa Catarina - Brazil}

\begin{abstract}
A B S T R A C T
In order to conserve water resources and existing vegetation in the Rio Maior river basin, the Rio Maior Environmental Preservation Area (EPA) was created through the Municipal Law no. 1,665 / 1998. However, besides its creation defined by law, it is necessary to manage it, which did not occur in the EPA of Rio Maior. Twenty years after the creation of the Advisory Council, the management plan has not yet been established. Given this context involving the EPA of Rio Maior, a study was developed that aims to characterize the physical, socioeconomic and socioenvironmental aspects of the territory where the EPA is inserted. In order to reach the proposed objective, we used documentary research, bibliographical research and geoprocessing. Because of the study, cartographic products of geology, mineral resources, geomorphology, slope, altimetry, pedology, climate, hydrography, vegetation, historical aspects, and population residing in communities EPA, land structure, agricultural activities, commercial, industrial and service activities, aspects related to land use and land cover, and socio-environmental impacts. The associative and specific thematic maps produced are information that can promote the qualitative and quantitative analyzes for the purposes of simulations and decision making in the context of the elaboration of the management plan.
\end{abstract}

Key words: Conservation unit (CU). Geoprocessing. Environmental analysis.

\section{Introdução}

A exploração dos recursos naturais pelos seres humanos vem há décadas sendo alvo de crescente preocupação e questionamentos, sendo que muito se tem debatido sobre a conservação ambiental e a recuperação dos ecossistemas degradados (Bailly et al., 2012). No sul do Estado 
de Santa Catarina, a preocupação ambiental de forma mais efetiva iniciou na década de 1980, principalmente em relação aos impactos provenientes das práticas de extração de carvão.

As atividades de mineração na bacia carbonífera localizada no sul do estado de Santa Catarina geraram aproximadamente 5.300 hectares de áreas degradadas, afetando, principalmente, a qualidade dos recursos hídricos (Amboni et al., 2011).

Apesar de ser responsável, em grande parte, pelo desenvolvimento econômico do sul do Estado de Santa Catarina durante algumas décadas, a extração de carvão mineral de forma desequilibrada, alterou significativamente a paisagem natural e degradou os recursos naturais de diversos municípios. Ao encerrarem as atividades em determinadas minas, as carboníferas deslocaram-se para novos sítios de exploração, deixando para trás um passivo ambiental, que em alguns locais permanece até hoje.

As áreas degradas pela mineração resultaram em uma Ação Civil $n^{\circ}$ 93.8000533-4 (Autos Suplementares $\mathrm{n}^{\circ}$ 2000.72.04.002543-9), "que condenou os réus, solidariamente, a apresentarem projetos de recuperação ambiental da região que compõe a Bacia Carbonífera do Sul do Estado" (BRASIL, 2009). Dessa forma, foi criado o Programa de Monitoramento Ambiental dos Recursos Hídricos Superficiais da Bacia Carbonífera que tem como objetivo avaliar a evolução da qualidade da água das bacias dos rios Araranguá, Tubarão e Urussanga.

A bacia hidrográfica do rio Maior está inserida na bacia hidrográfica do rio Urussanga, que é considerada como uma área crítica com relação à disponibilidade e qualidade das águas em função, principalmente, da degradação provocada pela extração do carvão mineral. A captação de água para o abastecimento público do município de Urussanga é feita nos afluentes localizados na margem esquerda do rio Urussanga, e o rio Maior é dos principais afluentes (Pereira, 2016).

O município de Urussanga por meio da Lei $\mathrm{n}^{\circ} 1.665 / 199$, criou a Área de Proteção Ambiental (APA) do Rio Maior, que abrange a mesma área da bacia hidrográfica do Rio Maior. A APA foi criada com o objetivo de garantir a conservação de expressivos remanescentes de floresta ribeirinha e dos recursos hídricos ali existentes; melhorar a qualidade de vida da população residente mediante a orientação e disciplina das atividades econômicas locais; fomentar o turismo ecológico, a educação ambiental e a pesquisa científica; preservar o conjunto arquitetônico do meio rural; além de proteger espécies ameaçadas de extinção (Urussanga, 1998).

A criação de áreas protegidas, por legislação federal, estadual ou municipal, tem surgido como uma alternativa para preservação e conservação dos recursos naturais.

$\mathrm{O}$ planejamento das atividades envolvendo unidades de conservação deve seguir orientação dos instrumentos de gestão propostos na Lei ${ }^{\circ}$ 9985/2000, que institui o Sistema Nacional de Unidades de Conservação (SNUC) (BRASIL, 2000). A lei estabelece que toda unidade de conservação (UC), após criada, tem um prazo máximo de cinco anos para elaborar um plano de manejo. O plano de manejo é o documento técnico oficial de uma UC, que estabelece seu zoneamento $\mathrm{e}$ as normas que devem presidir o uso da área e o manejo dos recursos naturais conforme a modalidade de uso da UC. As modalidades previstas de uso são: proteção integral e uso sustentável. As áreas de proteção ambiental (APA) se enquadram no SNUC como áreas de uso sustentável.

No caso específico da APA do Rio Maior, a situação é lastimável. Apesar de ter sido criada com objetivo muito claro, esse não foi alcançado. Quase duas décadas após a criação da APA, a Prefeitura Municipal de Urussanga não iniciou o processo de elaboração do Plano de Manejo, que deveria ter sido implantado até o ano de 2003. Em 2010, o Ministério Público Federal (MPF), na recomendação $\mathrm{n}^{\circ}$ 21/2010, cobrou do órgão executivo municipal de Urussanga a instituição do conselho da APA e do plano de manejo, afirmando ainda que a área só existia "no papel", tamanha a inércia do poder público municipal frente à sua efetivação. Em dezembro de 2010, em resposta à recomendação do MPF, foi criada a Lei $\mathrm{n}^{\mathrm{o}} 2.489$, que dispõe sobre a criação do conselho consultivo da APA, porém esse nunca foi instituído (MPF, 2010).

O presente trabalho se propõe a realizar um diagnóstico físico-social, com objetivo de subsidiar a elaboração do plano de manejo da APA.

\section{Localização da área de estudo}

A APA do Rio Maior, que é área de estudo da pesquisa, possui como limite geográfico os meridianos $49^{\circ} 26^{\prime} 12,9131^{\prime \prime} \mathrm{W}$; $49^{\circ} 01{ }^{\prime} 52,9012^{\prime \prime} \mathrm{W}$ e os paralelos $28^{\circ} 25^{\prime} 04,3882^{\prime \prime}$; $28^{\circ} 49^{\prime} 07,2658^{\prime \prime}$ (Figura 1). 


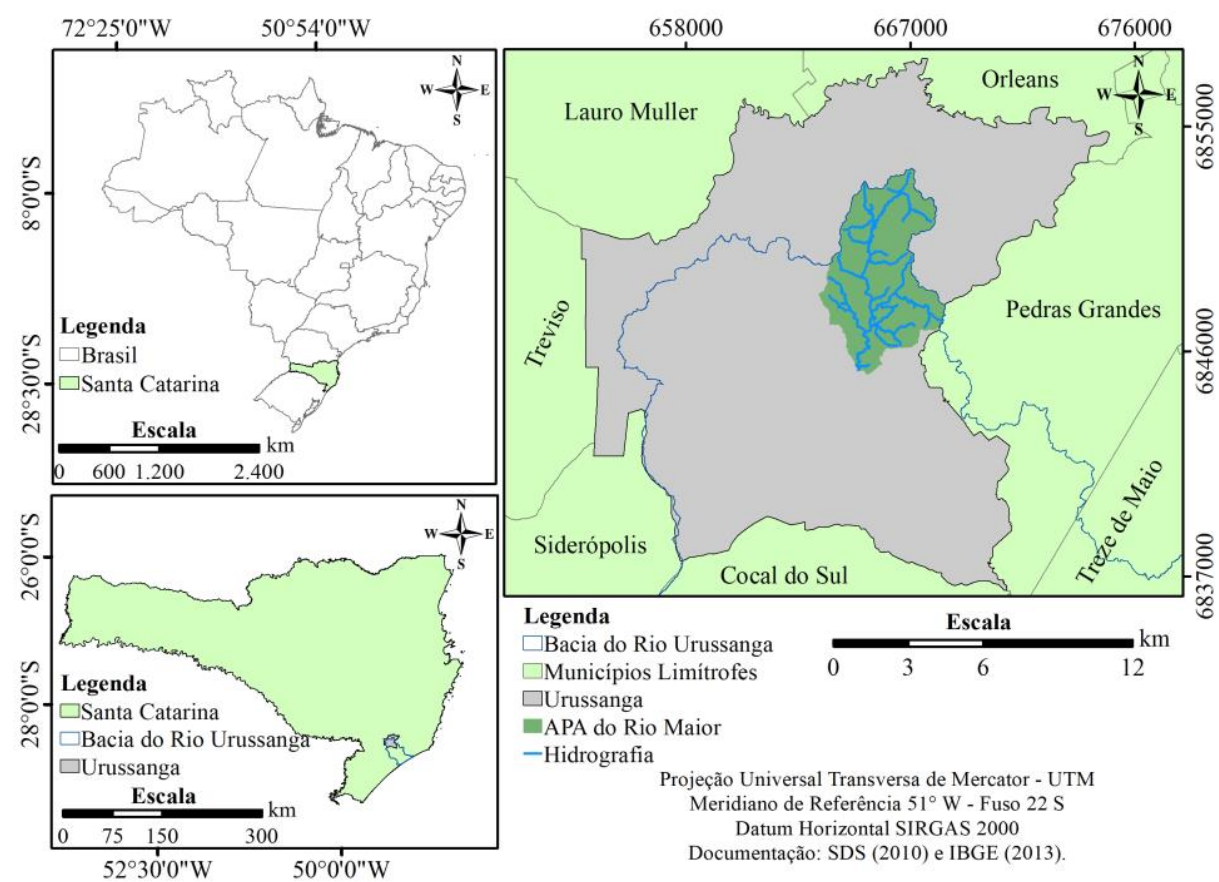

Figura 1 - Localização geográfica da APA do Rio Maior. Fonte: autores.

Está localizada no município de Urussanga, no estado de Santa Catarina, Brasil. O município de Urussanga possui uma área territorial de 254,869 $\mathrm{km}^{2}$ (IBGE, 2017), enquanto a APA criada em 27 de novembro de 1998, por meio da Lei Municipal $\mathrm{n}^{\circ} 1665$, possui uma área de $24,28 \mathrm{~km}^{2}$. Sendo assim, 9,52\% da área total do município integram a APA do Rio Maior.

$\mathrm{O}$ município de Urussanga pertence à microrregião de Criciúma e integra a Associação dos Municípios da Região Carbonífera (AMREC). A bacia hidrográfica do rio Maior está inserida dentro da bacia hidrográfica do rio Urussanga, tendo na sua confluência com o rio Carvão a formação do rio Urussanga.

A principal via de acesso à área é a rodovia SC-108. A área de estudo possui três comunidades rurais: Linha Rio Maior, São João do Rio Maior e Rio Maior.

A APA Rio Maior tem como função principal a proteção dos recursos hídricos. Configura-se como um espaço de preservação e conservação dos recursos naturais e do patrimônio cultural e arquitetônico, de melhoria da qualidade de vida das populações residentes, sendo uma área para fomentar o turismo ecológico, a educação ambiental e a pesquisa científica.

\section{Material e métodos}

A fim de alcançar os objetivos propostos, foram utilizadas as seguintes técnicas de pesquisa: pesquisa documental, pesquisa bibliográfica, pesquisa de campo e rotinas em geoprocessamento.
Segundo Gil (1999), a pesquisa documental é muito semelhante à pesquisa bibliográfica, a diferença está na natureza das fontes. Enquanto a pesquisa bibliográfica se utiliza fundamentalmente das contribuições de diversos autores sobre o assunto, a pesquisa documental utiliza materiais que não receberam ainda um tratamento analítico, ou que ainda podem ser reelaborados de acordo com os objetivos da pesquisa.

A pesquisa documental neste trabalho utilizou documentos, relatórios, leis, decretos, normas do município de Urussanga, do Comitê da Bacia Hidrográfica do Rio Urussanga, e do censo realizado pelo IBGE (Instituto Brasileiro de Geografia e Estatística) em 2010. E a pesquisa bibliográfica buscou a identificação de referências para auxiliar o curso da pesquisa, dentre as quais se destacam monografias, dissertações, teses, livros e artigos técnicos e científicos relacionados ao tema em questão. As pesquisas documental e bibliográfica possibilitaram a obtenção do referencial teórico necessário para elucidar questões relacionadas aos aspectos sociais, econômicos, políticos e ambientais que perpassam a análise em questão.

A pesquisa de campo consistiu na observação de fatos e fenômenos tal como ocorrem espontaneamente, na coleta de dados a eles referentes e no registro de variáveis que se presume relevantes para analisá-los (Marconi; Lakatos, 2011). A pesquisa precisou recorrer ao trabalho de campo para verificar resultados obtidos in loco e para buscar informações 
complementares relacionadas aos aspectos socioambientais e socioeconômicos.

O geoprocessamento é conhecido como um conjunto de técnicas e recursos para o armazenamento e a análise de dados especializados e nglobando processamento digital de imagens, cartografia digital e os sistemas informativos geográficos (Moura, 2014). O emprego da cartografia digital permitiu a elaboração de mapas base e temáticos, que foram organizados conforme a necessidade da pesquisa. Os materiais cartográficos utilizados para a elaboração da cartografia de base e temática foram adquiridos junto aos órgãos oficiais (federal e estadual) e Laboratório de Pesquisa em Planejamento e Gestão Territorial (LabPGT/UNESC). No quadro 1, estão listados todos os elementos utilizados para a construção dos produtos básicos e temáticos.

Quadro 1 - Fonte das informações e dados para construção dos produtos cartográficos

\begin{tabular}{|c|c|}
\hline $\begin{array}{c}\text { Bases } \\
\text { cartográficas/imagens }\end{array}$ & Fonte \\
\hline $\begin{array}{l}\text { Divisão municipal do } \\
\text { estado de SC }\end{array}$ & IBGE (2013) \\
\hline $\begin{array}{l}\text { Divisão territorial do } \\
\text { Brasil }\end{array}$ & IBGE (2013) \\
\hline Geomorfologia & LabPGT (2016) \\
\hline Hidrográfica & ANA (2010) \\
\hline $\begin{array}{l}\text { Limite da APA do Rio } \\
\text { Maior }\end{array}$ & $\begin{array}{c}\text { PMU - DEPLAN } \\
\text { (2017) }\end{array}$ \\
\hline Malha viária & CPRM (2016) \\
\hline $\begin{array}{l}\text { Modelo digital de terreno } \\
(\mathrm{MDT})\end{array}$ & SDS-SC (2011) \\
\hline Ortofoto do estado de SC & SDS-SC (2011) \\
\hline Pedologia & LabPGT (2016) \\
\hline Recursos minerais & CPRM (2016) \\
\hline Regiões fitoecologicas & IFFSC (2013) \\
\hline $\begin{array}{l}\text { Unidade de conservação } \\
\text { do estado de SC }\end{array}$ & $\begin{array}{c}\text { CPRM (2016) e CNUC } \\
\text { (2017) }\end{array}$ \\
\hline Uso e ocupação da terra & SILVA, V. R. (2011) \\
\hline
\end{tabular}

Fonte: autores.

Para elaboração do mapa de uso e cobertura da terra, foram utilizados os mapas temáticos de uso e cobertura da terra elaborados por Silva (1998) usando técnica de fotointerpretação de fotografias aéreas dos anos de 1957, 1978 e 1996 na escala 1:25000. Os mapas temáticos dos anos citados acima foram elaborados originalmente em cartografia analógica, e posteriormente foram digitalizados e armazenados em ambiente de Sistema de Informação Geográfico.

O mapa temático do ano 2011 foi elaborado a partir da interpretação de imagem digital ortorretificada composição com as bandas vermelha, verde e azul com resolução espacial de 0,37 metros. Nessa imagem, foram definidas as seguintes classes de uso do solo: vegetação secundária, agricultura, pastagem, reflorestamento, extração de diabásio, extração de argila e área urbanizada.

A base cartográfica trabalhada e produzida na pesquisa foi processada no sistema de Projeção Universal Transversa de Mercator (UTM), datum SIRGAS 2000, meridiano de referência $51^{\circ} \mathrm{W}$ (Fuso $22 \mathrm{~S}$ ). Com a base cartográfica, as imagens disponíveis e os dados coletadas em campo, foram elaborados os mapas temáticos com o auxílio do software ArcGIS 10.3.1 licenciado pela Universidade do Extremo Sul Catarinense - UNESC.

\section{Resultados e discussão}

Os resultados obtidos a partir dos procedimentos metodológicos descritos permitiram a organização do diagnóstico da APA do Rio Maior.

\section{Caracterização física da APA do Rio Maior}

A geologia da região sul do Brasil compreende três domínios geológicos: PréCambriano, Bacia do Paraná e Cobertura Sedimentar Cenozoica (MAACK, 2001). Em Santa Catarina, a Bacia do Paraná ocupa cerca de dois terços do estado, estendendo-se de maneira contínua desde a borda oeste do embasamento cristalino, junto à Costa Atlântica, até a fronteira do Brasil com a Argentina (Viero; Silva, 2016).

Pode-se caracterizar a Bacia do Paraná em três grupos distintos que pertencem ao período Permiano: grupo Itararé (Formações Rio do Sul), grupo Guatá (Formações Rio Bonito e Palermo) e Passa dois (Formações Irati, Serra Alta, Teresina e Rio do Rasto). Já o Grupo São Bento (Formações Botucatu e Serra Geral) representa o período Jurássico e Cretáceo da era Mesozoica (Silva, 2011).

A APA do Rio Maior é formada por duas unidades diferentes: Terrenos Pré-cambrianos da Suíte Intrusiva Pedras Grandes e Sedimentos Permianos da Cobertura Gonduânica (Bacia do Paraná, com formações Rio do Sul e Rio Bonito) (Figura 2) (Silva, 1998).

Suíte Intrusiva Pedras Grandes é o termo utilizado por Trainini et al. (1978) para reunir diversos corpos de granitóides alcalinos que ocorrem no sul de Santa Catarina. Esse suíte é formado por um batólito de forma alongada, com aproximadamente $150 \mathrm{~km}$ de extensão, ocorrendo desde Biguaçu, no norte do estado, até próximo de 
Criciúma no Sul (Silva, 1987). Na área de estudo, o Suíte (Figura 2) ocorre na parte leste da APA e é muito dissecada, formando colinas.

A formação Rio do Sul constitui a parte superior do Grupo Itararé, sendo a sua porção basal constituída por espesso pacote de folhelho negro que representa depósito marinho profundo ou prodeltaico (Orlandi Filho; Krebs; Giffoni, 2006) A espessura média atribuída ao conjunto de sedimentos dessa formação é de 55 metros, e pode atingir até 100 metros. A formação Rio do Sul foi depositada sobre o Suíte Intrusiva Pedras Grandes (Silva, 1998).

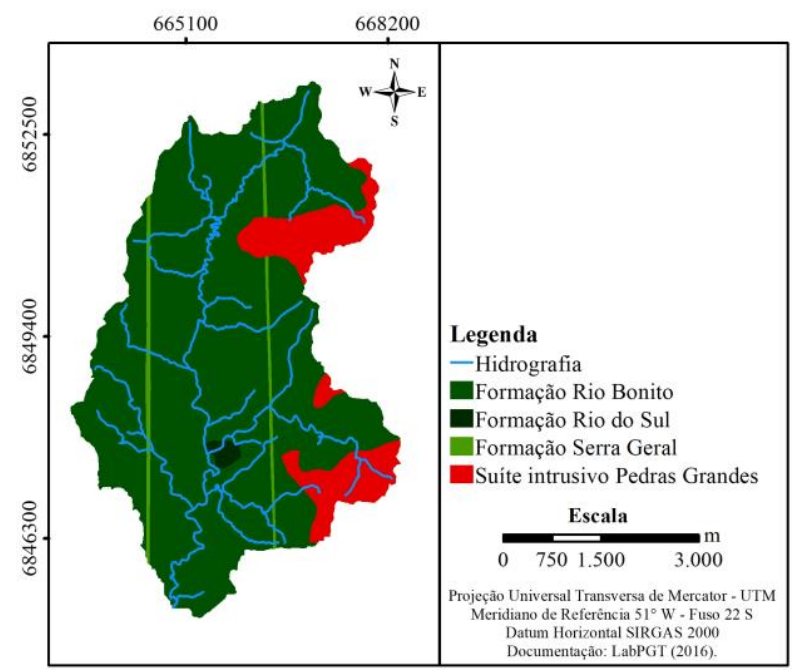

Figura 2- Mapa geológico da APA do Rio Maior.

Fonte: autores.

Formação Rio Bonito foi uma denominação proposta por White (1908 apud ORLANDI FILHO; KREBS; GIFFONI, 2006) a fim de caracterizar o conjunto de rochas arenítico associado a pelitos contendo camadas de carvão. É a formação com maior área de abrangência dentro da APA/bacia do Rio Maior. Sua espessura total chega a 250 metros. Ela se depositou de maneira proporcional sobre a Formação Rio do Sul, entretanto podem ocorrer desproporcionalidades sobre as rochas da Suíte Intrusiva Pedras Grandes.

Em 1908, White utilizou pela primeira vez a designação Serra Geral. Refere-se à província magmática relacionada aos derrames e intrusivas que recobrem a área de $1,2 \times 10^{6} \mathrm{~km}^{2} \mathrm{da}$ Bacia do Paraná, abrangendo toda a região centrosul do Brasil e estendendo-se ao longo das fronteiras do Paraguai, Uruguai e Argentina (Viero; Silva, 2016).

As rochas vulcânicas da Formação Serra Geral constituem a escarpa superior do planalto gonduânico. É muito frequente a intrusão de diabásios em rochas sedimentares gonduânicas. Constatou-se que essas intrusões ocorrem, principalmente, no intervalo estratigráfico correspondente às Formações Rio Bonito e Irati e à base da Formação Estrada Nova (Trein, 2008).

No trabalho realizando por Silva (1998), foram identificados dois sills de diabásio na direção norte-sul intercalados entre sedimentos da Formação Rio Bonito. No sil localizado mais a oeste da APA, hoje ocorre a extração de diabásio/basalto para produção de brita usada na construção civil e como material na pavimentação de rodovias.

Na APA do Rio Maior, existem duas áreas de exploração mineral em atividade, uma de diabásio e outra de argila (Figura 3). Área de extração de diabásio/basalto em atividade é a Unidade de Extração, Britagem e Usinagem de Asfalto de Rio Maior da empresa SETEP, que possui a concessão da lavra. Já a área de extração de argila/caulim é de responsabilidade da empresa Cecrisa, que possui a concessão da lavra.

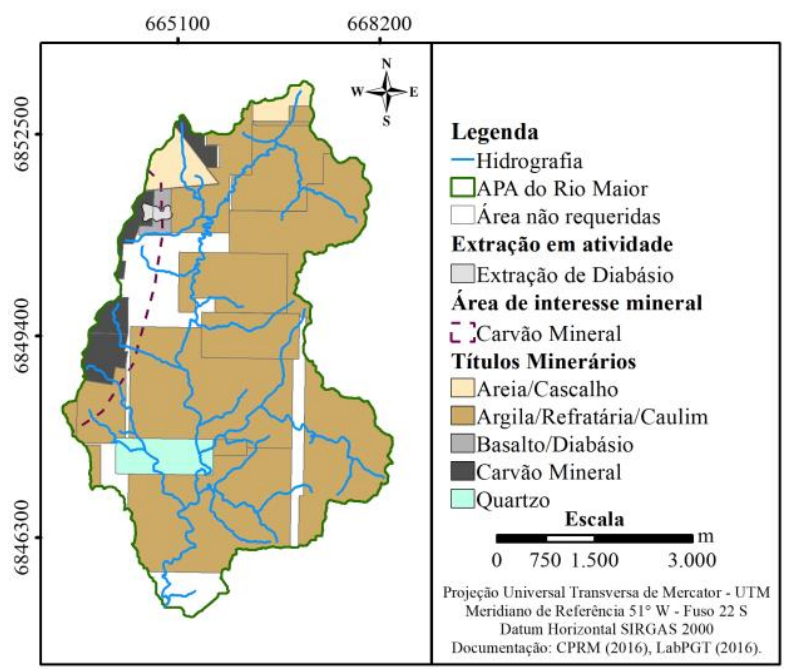

Figura 3 - Área de mineração em atividade, títulos minerários requeridos e área de interesse mineral na APA do Rio Maior. Fonte: autores.

Além dessas duas áreas em atividade, existem outras áreas requeridas ao Departamento Nacional de Produção Mineral (DNPM) para mineração na APA (Tabela 1 e Figura 3). Os valores da Tabela 2 revelam que $88 \%$ da área total da bacia hidrográfica, já foram requeridos para mineração, destacando-se a extração de argila para aterro, argila refratária e o caulim. Ainda é possível visualizar as extrações em andamento e as áreas requeridas para mineração, e um polígono de interesse mineral. Segundo a CRPM e o DNPM, essa seria uma área de interesse para a extração de carvão mineral. 
Tabela 1 - Áreas requeridas para mineração na APA do Rio Maior

\begin{tabular}{lrr}
\hline Títulos Minerários & Área (ha) & Área (\%) \\
\hline Argila/Refratária/Caulim & 1668 & 68,69 \\
Carvão mineral & 113 & 4,65 \\
Areia/Cascalho & 238 & 9,80 \\
Diabásio/Basalto & 22 & 0,90 \\
Quartzo & 82 & 3,37 \\
Sem requerimento & 305 & 12,56 \\
\hline Total & 2428 & 100,00 \\
\hline Fonte: CPRM (2016). & &
\end{tabular}

A APA do Rio Maior está inserida em dois diferentes domínios geológicos em Santa Catarina: embasamento cristalino e cobertura sedimentar gonduânicas. No embasamento cristalino, as formas do relevo constituem a Serra do Leste Catarinense; já a cobertura sedimentar gonduânica (bacia do Paraná) constitui a Unidade Geomorfológica Depressão da Zona Carbonífera Catarinense. Ainda no Quadro 2, é possível visualizar a divisão taxonômica do relevo na APA/bacia.

Quadro 2 - Divisão taxonômica do relevo na APA do Rio Maior

\begin{tabular}{|llll|}
\hline \multicolumn{1}{|l|}{ Domínio Morfoestrutural } & & \\
Enbasamento & Unidades Geomorfológicas & \\
\cline { 2 - 4 } Cristalino & Serras do & Modelados & \\
& Leste & Dissecação & Outeiro \\
& Catarinense & & Colina \\
Sedimentos & Depressão & Dissecação & Outeiro \\
da Bacia do & Zona & & Colina \\
Paraná & Carbonífera & Acumulação & Terração \\
& Catarinense & & Fluvial \\
\hline
\end{tabular}

Fonte: Adaptado de Silva (1998).

Várias divisões do revelo brasileiro foram propostas por diferentes autores, este trabalho utilizou a o método taxonômico que engloba a hierarquização domínios morfoestruturais, as regiões geomorfológicas, as unidades geomorfológicas e os tipos de modelado. Os domínios morfoestruturais compreendem os maiores táxons na compartimentação do relevo. Ocorrem em escala regional e organizam os fatos geomorfológicos segundo o arcabouço geológico marcado pela natureza das rochas e pela tectônica que atua sobre elas (IBGE, 2009).

As regiões geomorfológicas, representam o segundo nível na classificação do relevo, compartimentos inseridos nos conjuntos litomorfoestruturais que, sob a ação dos fatores climáticos pretéritos e atuais, lhes conferem características genéticas comuns, agrupando feições semelhantes, associadas às formações superficiais e às fitofisionomias. As unidades geomorfológicas são o terceiro nível taxonômico, elas são definidas como um arranjo de formas altimétrica e fisionomicamente semelhantes em seus diversos tipos de modelados. A quarta ordem é a dos modelados, um polígono de modelado abrange um padrão de formas de relevo que apresentam definição geométrica similar em função de uma gênese comum e dos processos morfogenéticos atuantes, resultando na recorrência dos materiais correlativos superficiais (IBGE, 2009).

A unidade geomorfológica Serras do Leste Catarinense estende-se por uma área de aproximadamente $13.143 \mathrm{~km}^{2}$ de Joinville até Laguna. É caracterizada por uma sequência de serras dispostas de forma subparalela, orientadas no sentindo NE-SO. O relevo é bastante dissecado, e os vales são profundos com encostas íngremes (EMBRAPA, 2014). Na APA, essa unidade está presente na borda da bacia, onde as altitudes variam de 300 a 400 metros (Figura 4), os vales com um formato de "v", ocorrem geralmente nas encostas.

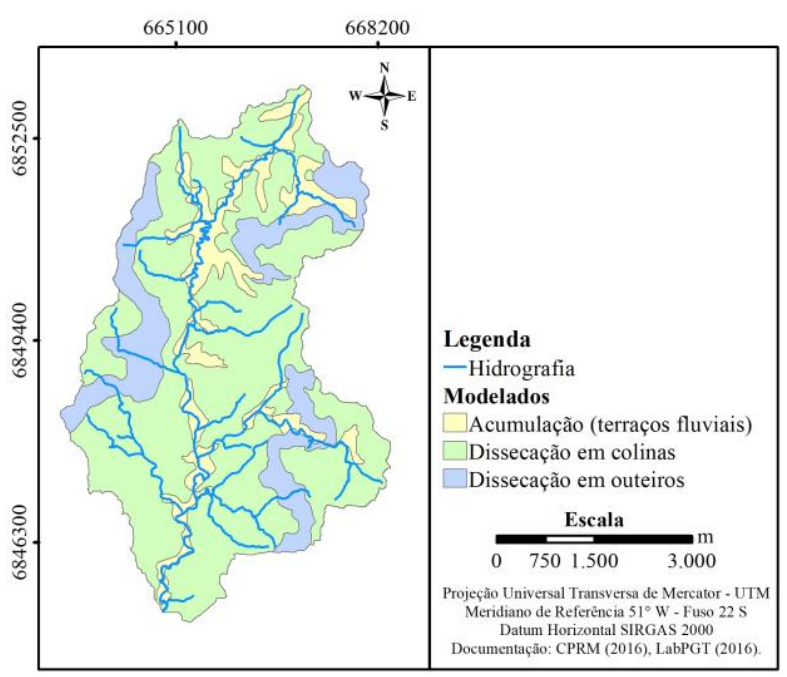

Figura 4 - Mapa geomorfológico da APA do Rio Maior. Fonte: autores.

A unidade geomorfológica Depressão da Zona Carbonífera Catarinense estende-se por cerca de $1.659 \mathrm{~km}^{2}$ no extremo sul de Santa Catarina. Essa unidade ocorre em uma faixa na direção norte-sul, sendo que, onde está localizada a APA, o relevo apresenta feições com formas côncavo-convexos com vales abertos, denominados de colinas. A dissecação colinosa que predomina na área apresenta vales poucos encaixados e abertos com amplitudes altimétricas baixas, em 200 a 300 metros (SILVA, 1998; EMBRAPA, 2014).

Na Acumulação Terraço Fluvial, as áreas têm forma plana, levemente inclinada, apresentando ruptura de declive em relação ao leito do rio e às várzeas recentes situadas em nível 
inferior, entalhada devido às mudanças de condições de escoamento e consequente retomada de erosão. Ocorre nos vales contendo aluviões finas a grosseiras, pleistocênicas e holocênicas (IGBE, 2009).

Desde a nascente do rio Maior até a sua foz junto ao rio Carvão, ocorre acumulação de terraço fluvial, sendo que a maior concentração é observada na faixa de 100 a 250 metros de altitude (Figura 4). Os terraços, em geral, são modelados planos com pequena inclinação para o canal, apresentando uma ruptura de declive em relação ao leito do rio (Silva, 1998).

Os fundos de vale da APA do Rio Maior correspondem aos modelados fluviais, que se concentram ao longo do rio Maior.

Declividade até $20 \%$ corresponde às áreas com dissecação em colina. Declividade de 20 $45 \%$ corresponde às áreas com modelados de dissecação de morraria ou o outeiro e às áreas menores próximas aos limites da APA com modelado de dissecação em colina. Declividade maior que $45 \%$ corresponde apenas ao modelado de dissecação em morraria ou outeiro (Figura 5).

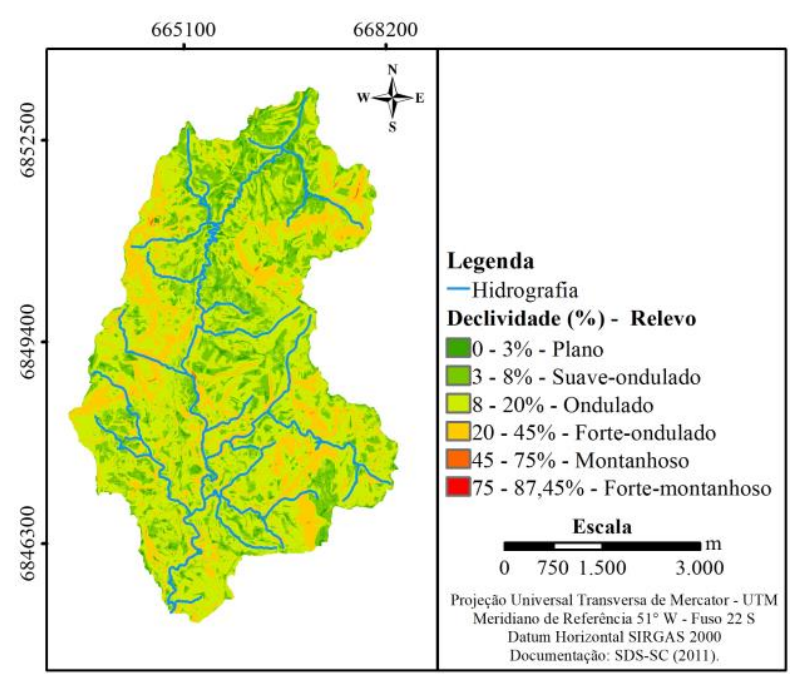

Figura 5 - Mapa de declividade da APA do Rio Maior. Fonte: autores.

As variações declividade da APA foram determinadas conforme EMBRAPA (1979), o relevo com maior porcentagem de área é o relevo ondulado $(53,27 \%)$; e o relevo com menor porcentagem de área é o forte-montanhoso (Tabela 2).

Tabela 2 - Distribuição da declividade na APA

\begin{tabular}{llll}
\hline $\begin{array}{l}\text { Declividade } \\
(\%)\end{array}$ & Relevo & $\begin{array}{l}\text { Área } \\
\text { (ha) }\end{array}$ & $\begin{array}{l}\text { Área } \\
(\%)\end{array}$ \\
\hline $0-3 \%$ & Plano & 79,11 & 3,25 \\
$3-8 \%$ & $\begin{array}{l}\text { Suave } \\
\text { ondulado }\end{array}$ & 427,09 & 17,58 \\
& & \\
$8-20 \%$ & Ondulado & 1293,81 & 53,27 \\
$20-45 \%$ & Forte- & 615,03 & 25,32
\end{tabular}

ondulado

\begin{tabular}{llll}
$45-75 \%$ & Montanhoso & 13,27 & 0,54 \\
$75-85 \%$ & $\begin{array}{l}\text { Forte- } \\
\text { montanhoso }\end{array}$ & 0,02 & 0,000927 \\
& & \\
\hline
\end{tabular}

Fonte: autores.

As variações de altitudes encontradas na área de estudo variam de 41 metros até 428 metros. Com uma altitude média de 247 metros. Com base na Tabela 3, é possível afirmar que $88,57 \%$ da área da APA está entre 100 a 350 metros de altitude, sendo que a faixa de altitude com maior área é a de 200 a 250 metros que corresponde a $32,91 \%$ da área total da APA (Figura 6).

Tabela 3 - Distribuição hipsométrica da APA

\begin{tabular}{l|c|c}
\hline Altimetria (m) & Área (ha) & Área (\%) \\
$41-50$ & 4,16 & 0,17 \\
$50-100$ & 148,64 & 6,12 \\
$100-150$ & 312,44 & 12,86 \\
$150-200$ & 283,5 & 11,67 \\
$200-250$ & 799,26 & 32,91 \\
$250-300$ & 430,45 & 17,72 \\
$300-350$ & 325,23 & 13,39 \\
$350-400$ & 113,73 & 4,68 \\
$400-428$ & 10,91 & 0,44 \\
\hline
\end{tabular}

Fonte: autores.

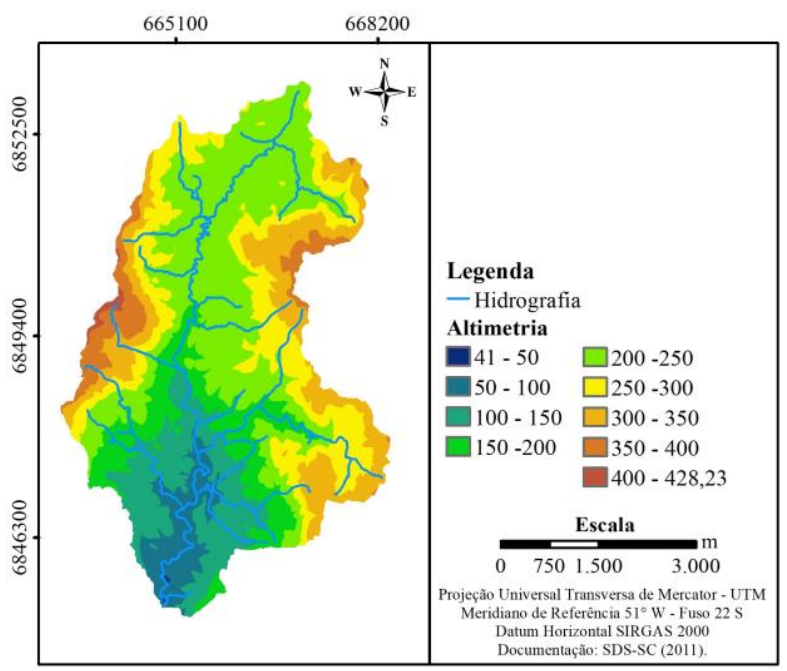

Figura 6 - Mapa hipsométrico da APA do Rio Maior. Fonte: autores.

O Sistema Brasileiro de Classificação de Solos (SiBCS) é o sistema taxinômico oficial para a classificação dos solos no Brasil. Com intuito de nacionalizar a classificação, foi lançada uma série de manuais, sendo a $4^{\text {a }}$ edição do SiBCS de 2013 a versão mais atualizada. Com base nessa edição, foram classificados os solos da APA do Rio Maior (EMBRAPA, 2014).

O SiBCS estabelece 6 níveis categóricos para classificar os solos segundo a EMPRAPA (2014): ordens, subordens, grandes grupos, subgrupos, famílias e séries.

Sutil;T.; Ladwig; N. I.; Back; A.J.; De Conto, D. 
Em função dos dados disponíveis para identificar os tipos de solos da área de estudo, optou-se por classificar até o segundo nível categórico (subordem). Sendo assim, na área da APA ocorrem solos de duas ordens diferentes: argissolos e cambissolos. Suas subordens são, respectivamente, argissolos vermelho-amarelos (PVA) e cambissolos háplicos (CX) (Silva, 1998; Pereira, 2016).

Argissolos são definidos pelo SiBCS (EMBRAPA, 2014) pela presença de horizonte diagnóstico $\mathrm{B}$ textural, apresentando acúmulo de argila em profundidade devido à mobilização e à perda de argila da parte mais superficial do solo. Apresentam frequentemente, mas não exclusivamente, baixa atividade da argila, podendo ser alíticos (altos teores de alumínio), distróficos (baixa saturação de bases) ou eutróficos (alta saturação de bases), sendo normalmente ácidos.

A subordem dos argissolos vermelhoamarelo está presente em todo o território nacional, do Amapá ao Rio Grande do Sul, constituindo a classe de solo das mais extensas no Brasil, ao lado dos Latossolos. Ocorrem em áreas de relevos mais acidentados e dissecados.

Cambissolos são definidos pelo SiBCS (EMBRAPA, 2014) como solos pouco desenvolvidos, que ainda apresentam características do material originário (rocha) evidenciado pela presença de minerais primários. São definidos pela presença de horizonte diagnóstico $\mathrm{B}$ incipiente, apresentando baixa (distróficos) ou alta (eutróficos) saturação por bases, baixa a alta atividade da argila.

A subordem dos cambissolos háplicos é identificada, normalmente, em relevo forte ondulado ou montanhoso, que não apresenta horizonte superficial A húmico. São solos de fertilidade natural variável. Apresentam como principais limitações para uso o relevo com declives acentuados, a pequena profundidade e a ocorrência de pedras na massa do solo.

O solo predominante na APA são os argissolos vermelho-amarelos, que ocupam $97,11 \%$ da área total, seguido dos cambissolos háplicos, que ocupam $2,47 \%$. O restante da área $(0,41 \%)$ é caracterizado por uma mistura de argissolos e cambissolos (Tabela 4). Na Figura 7, é possível observar a distribuição espacial dos solos na área de estudo.

Tabela 4 - Classificação pedológica da APA do Rio Maior

\begin{tabular}{llll}
\hline Ordem & Subordem & $\begin{array}{l}\text { Área } \\
\text { (ha) }\end{array}$ & $\%$ \\
\hline Argissolos & Argissolos & 2358,32 & 97,11 \\
\hline
\end{tabular}

\begin{tabular}{llll}
\hline \multicolumn{4}{c}{$\begin{array}{l}\text { vermelho- } \\
\text { amarelos }\end{array}$} \\
\hline Cambissolos & $\begin{array}{l}\text { Cambissolos } \\
\text { háplicos }\end{array}$ & 60,2 & 2,47 \\
\hline Argissolos e & $\begin{array}{l}\text { Argissolos } \\
\text { Cambissolos } \\
\text { vermelho- } \\
\text { amarelos }\end{array}$ & 9,84 & 0.41 \\
& $\begin{array}{l}\text { Cambissolos } \\
\text { háplicos }\end{array}$ & & \\
&
\end{tabular}

Fonte: autores.

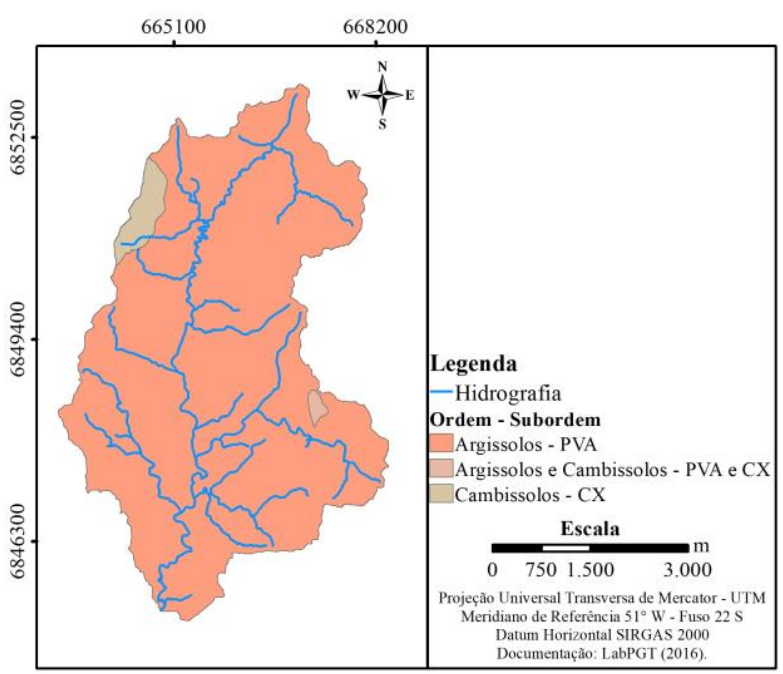

Figura 7 - Mapa pedológico da APA do Rio Maior. Fontes: autores.

Segundo Back (1999) e Trein (2008), a caracterização climática de uma região deve levar em consideração uma série de fatores: radiação solar, latitude, continentalidade, massas de ar e correntes oceânicas. Esses fatores condicionam os elementos climáticos, como temperatura, precipitação, umidade do ar, pressão atmosférica, entre outros.

O clima da região sul de Santa Catarina é geralmente classificado como do tipo $\mathrm{Cfa}$ mesotérmico, úmido e com verão quente, segundo a classificação climática de Köppen, embora haja variações significativas em alguns elementos climáticos, como precipitação e temperatura (Back, 2010). Segundo estudos de Dufloth et al. (2005), o município de Urussanga, no qual está inserida a APA do Rio Maior, apresenta a seguintes características apresentadas na Quadro 3.

Quadro 3 - Características climáticas de Urussanga

\begin{tabular}{|l|l|}
\hline \multicolumn{1}{|c|}{ Características } & \multicolumn{1}{c|}{ Urussanga } \\
\hline Classificação de Köppen & Cfa \\
\hline Classificação de Braga e & Mesotérmico brando \\
Ghellere & $(1)$ \\
\hline $\begin{array}{l}\text { Temperatura média anual } \\
\left({ }^{\circ} \mathrm{C}\right)\end{array}$ & $17,0-19,3$ \\
\hline
\end{tabular}




\begin{tabular}{|l|l|}
\hline $\begin{array}{l}\text { Temperatura do mês mais } \\
\text { frio }\left({ }^{\circ} \mathrm{C}\right)\end{array}$ & $13,0-15,0$ \\
\hline Hora abaixo de $7,2^{\circ} \mathrm{C}$ & $164-437$ \\
\hline $\mathrm{N}^{\circ}$ de geadas por ano & $0,3-11,0$ \\
\hline Umidade relativa anual $(\%)$ & $81,4-82,2$ \\
\hline $\begin{array}{l}\text { Precipitação total anual } \\
(\mathrm{mm})\end{array}$ & $1.222-1.660$ \\
\hline Dias de chuva $\left(\mathrm{n}^{\circ}\right)$ & $102-150$ \\
\hline Insolação anual $(\mathrm{h})$ & $1.885-2.182$ \\
\hline
\end{tabular}

Fonte: Dufloth et al. (2005).

As características da bacia hidrográfica, como o tamanho, a forma e a declividade, influenciam o comportamento hidrológico desta bacia. O volume de escoamento, a vazão de pico, velocidade e o tempo de escoamento e o transporte sedimento estão relacionados com as características físicas da bacia (BACK, et al., 2016).

Nesse sentindo, os índices físicos da bacia hidrográfica do rio Maior foram determinados por Back et al. (2016) e estão organizados na Tabela 5 .

Tabela 5 - Características físicas da bacia hidrográfica do rio Maior

\begin{tabular}{lc}
\hline & $\begin{array}{c}\text { Bacia do Rio } \\
\text { Maior }\end{array}$ \\
\hline $\begin{array}{l}\text { Área }\left(\mathrm{km}^{2}\right) \\
\text { Perímetro }(\mathrm{km})\end{array}$ & 24,28 \\
$\begin{array}{l}\text { Comprimento da } \\
\text { bacia }(\mathrm{km})\end{array}$ & 39,497 \\
$\begin{array}{l}\text { Comprimento do rio } \\
(\mathrm{km})\end{array}$ & 10,152 \\
$\begin{array}{l}\text { Número de canais de } \\
\text { Densidade } \\
\text { drenagem }\left(\mathrm{km} / \mathrm{km}^{2}\right)\end{array}$ & 15,498 \\
$\begin{array}{l}\text { Amplitude } \\
\text { altimétrica }(\mathrm{m})\end{array}$ & 354 \\
$\begin{array}{l}\text { Declividade média } \\
(\mathrm{m} / \mathrm{m})\end{array}$ & 4,703 \\
\hline
\end{tabular}

Fonte: Back et al. (2016).

Uma das características de uma bacia hidrográfica é a ordem dos cursos d'água que são definidos por meio de suas ramificações. Dessa forma, a ordem da bacia é classificada com base no seu grau de ramificação, quanto maior a ordem da bacia, mais ramificada é a mesma. Os segmentos de rios iniciais são definidos de primeira ordem, enquanto que os segmentos de segunda ordem são estabelecidos pela confluência de dois segmentos de primeira ordem e assim sucessivamente (Horton, 1945, Strahler, 1957, Villela; Mattos, 1975).

No mapa hidrológico elaborado (Figura 8), pode-se observar o comportamento hídrico da bacia hidrográfica do rio Maior, sendo que essa possui rios de $4^{\mathrm{a}}$ ordem. Na Tabela 6 , é possível visualizar a distribuição e extensão dos corpos hídricos. Os corpos hídricos de $1^{\text {a }}$ ordem $(55,62)$ são os que predominam seguidos dos de ordem 3 $(25,31 \%)$.

Tabela 6 - Relação da ordem dos rios da bacia hidrográfica do rio Maior

\begin{tabular}{lccc}
\hline Ordem & Quantidade & $\begin{array}{l}\text { Extensão em } \\
(\mathrm{km})\end{array}$ & $\begin{array}{c}\text { Extensão em } \\
(\%)\end{array}$ \\
\hline $1^{\mathrm{a}}$ & 19 & 24,66 & 55,62 \\
$2^{\mathrm{a}}$ & 5 & 4,49 & 10,12 \\
$3^{\mathrm{a}}$ & 2 & 11,22 & 25,31 \\
$4^{\mathrm{a}}$ & 1 & 3,96 & 8,93 \\
\hline
\end{tabular}

Fonte: autores.

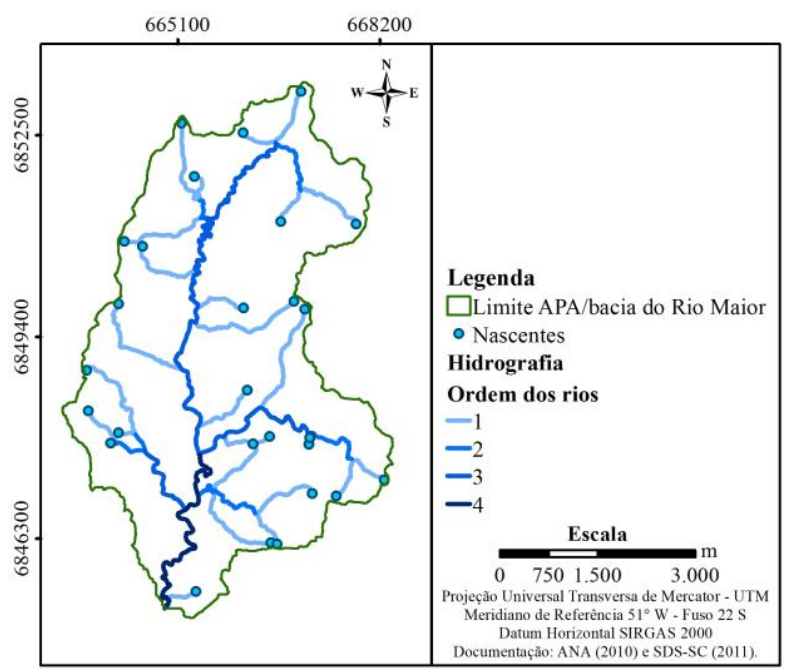

Figura 8 - Mapa hidrológico da Bacia Hidrográfica do rio Maior. Fonte: autores.

Klein (1978) subdividiu o estado de Santa Catarina nas seguintes regiões fitoecológicas: campos naturais, floresta estacional decidual, floresta ombrófila densa, florestas ombrófila mista e vegetação litorânea. No sul do estado, onde se encontra a APA do Rio Maior, há um predomínio da vegetação do tipo floresta ombrófila densa.

$\mathrm{Na}$ Floresta Ombrófila Densa, ocorrem distintas formações, que estão ligadas a diferentes estruturas das comunidades, resulta da interação entre fatores físicos, como feições geológicas, pedológicas e altitude (IBGE, 1992).

O tipo vegetacional Floresta Ombrófila Densa foi subdividido em cinco formações ordenadas segundo hierarquia topográfica que refletem fisionomias diferentes de acordo com as variações ecotípicas das faixas altimétricas:

a) formação aluvial: não condicionada topograficamente, apresenta sempre os ambientes repetitivos, dentro dos terraços aluviais dos flúvios;

b) formação das terras baixas: situada em áreas de terrenos sedimentares do 
terciário/quaternário de $5 \mathrm{~m}$ até em torno de $30 \mathrm{~m}$ de altitude;

c) formação submontana: situada nas encostas dos planaltos/serras de $30 \mathrm{~m}$ até em torno de $400 \mathrm{~m}$ de altitude;

d) formação montana: situada acima dos limites no alto dos planaltos e/ou serras, de $400 \mathrm{~m}$ até em torno de 1000 $m$ de altitude; $\mathrm{e}$

e) formação alto-montana: situada acima dos limites estabelecidos para formação Montana (Adami; Cunha, 2014).

Conforme o mapa (Figura 6) elaborado para área de estudo, é possível identificar que apenas $0,4 \%$ da área total está acima de $400 \mathrm{~m}$ de altitude, sendo assim sua vegetação é do tipo Floresta Ombrófila Densa Submontana.

A Floresta Ombrófila Densa Submontana, ocorre geralmente em solos com média profundidade, onde a vegetação arbórea no estrato superior possui uma altura uniforme. As árvores podem atingir até 30 metros de altura, a submata é composta por arvoretas, arbustos, palmeiras de pequeno porte e grande quantidade de lianas e epífitas (Silva, 2010).

A vegetação original da APA do Rio Maior era formada pela Floresta Ombrófila Densa Submontana, porém esse subtipo foi praticamente eliminado da APA no processo de colonização que teve início com a chegada de imigrantes italianos a partir do ano de 1878. Portanto, em um pequeno espaço de tempo, a vegetação original da área foi suprimida. Assim, ao longo do tempo, o desmatamento foi acontecendo com os mais diferentes objetivos: extração de madeira para construção de casas, lenha, agricultura, pecuária e mineração (Silva, 2010).

Nos últimos anos, a APA do Rio Maior é representada fisionomicamente pela vegetação secundária, em diversos estágios de sucessão ecológica, como pode ser observado na Figura 9 e também pela presença de reflorestamentos, como é o caso dos cultivos comerciais dos gêneros Eucalyptus, Acácia e Pinus.

A vegetação secundária é a vegetação mais comumente encontrada em área onde houve a intervenção humana com o intuito de utilizar o solo para atividades econômicas como agricultura, pecuária, mineração, entre outras, que acabam levando ao desmatamento da vegetação primária.

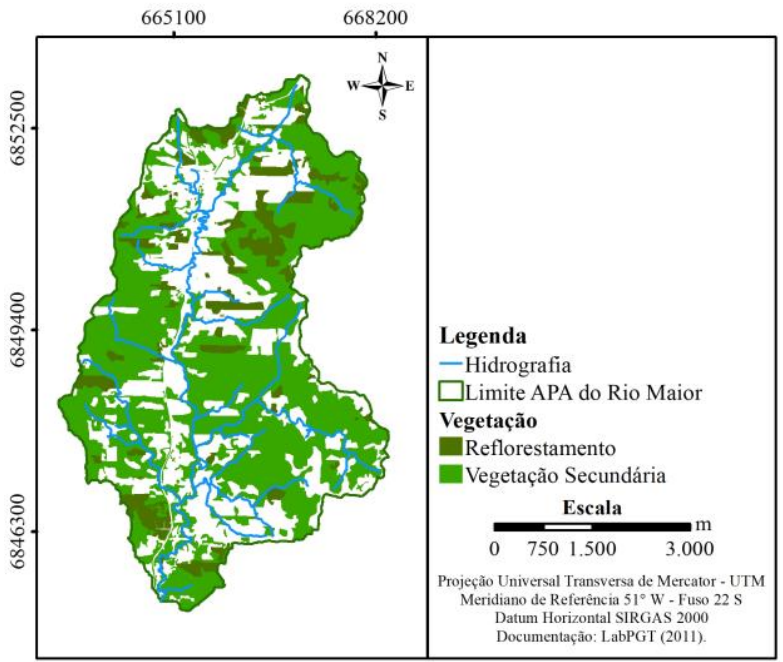

Figura 9 - Cobertura Vegetal da APA do Rio Maior. Fonte: autores.

\section{Caracterização socioeconômica da APA do Rio Maior}

O Estado de Santa Catarina, historicamente, era ocupado, em grande parte, pelo grupo indígena Xokleng (Lavina, 1994), ocupação essa que passou por uma transformação com o processo de colonização portuguesa, que deu início ao conflito entre os brancos e os povos nativos. Até meados do século XVII, a base do povoamento no estado era representada por povos indígenas, desertores, missionários e náufragos (Silva, 1998).

Em 1828, Santa Catarina recebe o primeiro contingente de imigrantes, influenciada pelas políticas de incentivo à colonização por imigrantes europeus, implementada pelo Governo Imperial. A colonização italiana teve início no estado em 1836, com a fundação da colônia "Nova Itália", área que atualmente faz parte do município de São João Batista (Silva, 1998).

Segundo Escaravaco (1984), um novo contingente de italianos chegou a Santa Catarina em 1877, que foram direcionados para o vale do rio Tubarão no sul do estado, área até então pouco povoada. Em maio de 1878, é fundado o núcleo de Urussanga, o núcleo de Rio Maior constitui-se assim como distrito sede de Urussanga, a ser ocupada pelos imigrantes italianos. Boa parte dos imigrantes italianos que se estabeleceram em Rio Maior era oriunda da localidade de Casso, atual município de Erto, província de Udine, na região de Vêneto, Itália.

Em 1880, com início da construção da estrada de ferro que ligaria Imbituba até Lauro Muller, muitos migrantes que haviam se estabelecido na Colônia de Urussanga foram trabalhar na construção da ferrovia para aumentar os ganhos familiares enquanto esperavam a colheita (Escaravaco, 1984). 
Muitas famílias imigrantes tiveram dificuldades para saldar as suas dívidas com a Companhia Colonizadora, já que, quando chegavam ao Brasil, tinham até dois anos para pagar o seu lote. Logo que chegaram, começaram a desmatar, preparar a terra para plantar, construir moradias e executar alguns trabalhos básicos de infraestrutura de rodagem, pois na região havia poucas estradas (Baldin, 1999).

Após se estabelecerem na região, muitos imigrantes sofreram com o clima distinto do qual era habituado. Contraíram algumas doenças, sendo que as mais comuns eram as relacionadas à pele (Baldessar, 2005).

Com a sistemática estabelecida para ocupação de imigrantes na colônia, ocorre uma significativa alteração da paisagem nos vales fluviais. A ideia de progresso não considerou a Mata Atlântica e sua importância, alterando assim o equilíbrio entre a flora e fauna local (Ferri, 2017).

Dentre os produtos mais cultivados nos primeiros anos de colonização, estão o milho, o feijão, o açúcar, o arroz e a aguardente. Os lotes recebidos pelos imigrantes tinham restrições quanto à fertilidade em função da topografia acidentada, que também dificultava a locomoção e transporte agrícola para comercialização. $\mathrm{O}$ meio de transporte utilizado era o carro de boi e a zorra (Silva, 1998; Ferri, 2017).

$\mathrm{O}$ início da pecuária se deu por meio de uma troca de mão de obra dos imigrantes para construção de taipas para os criadores de gado de São Joaquim na serra, que pagavam o trabalho com o gado. A criação de suínos teve bons resultados na região, tanto que em rio Maior foi montada uma fábrica de banha por José Mazzuco e seus irmãos. Possibilitando que em 1909 fosse criada Cooperativa Rio Maior, que funcionou até 1923 (Baldessar, 1991).

A partir da década de 1910, com a descoberta do carvão mineral e a abertura das minas, Urussanga, que havia se tornado município em 1901, passa se desenvolver economicamente, sendo que inaugura em 1918 a Companhia Carbonífera de Urussanga, porém a extração do carvão mineral não chegou às comunidades de Rio Maior, Linha Rio Maior e São João do Rio Maior (Tomasi, 2012).

Apesar da extração de carvão mineral não ter acontecido nas comunidades da APA do Rio Maior, as comunidades sentiram as consequências, já que, em razão da alta remuneração e curta carreira (15 anos de trabalho), muitos agricultores abandonaram $\mathrm{o}$ trabalho rural e optaram por trabalhar na extração de carvão mineral, causando, na década de 1940 , o declínio da atividade agrícola e ascensão do carvão.

Na década de 1980 e 1990, chega à colônia o cultivo de fumo, que tinha como vantagem a possibilidade de estocagem. Porém a comercialização do fumo era difícil. Apesar das dificuldades, a produção de fumo dava bons resultados financeiros (Baldessar, 2005). Nessa mesma época, além da produção de uva para fabricação de vinhos, cultiva-se a banana.

Nos anos 2000, surge um novo fluxo no município de Urussanga e, ao contrário do que havia acontecido no século passado, agora o fluxo era emigratório. Especialmente nas comunidades de Rio Maior, Linha Rio Maior e São João do Rio Maior, muitos jovens foram trabalhar na Alemanha, visto que muitos dos moradores possuem dupla cidadania ítalo-brasileira. Isso fez com que existisse um fluxo constante de investimentos movimentando a economia da cidade (Nascimento; Burstyn, 2012).

A colonização italiana deixou marcas na arquitetura das comunidades que estão inseridas na APA, a região ficou conhecida pela rota que os imigrantes atravessaram antes de chegarem ao município de Urussanga, e ainda sustenta os patrimônios construídos nos séculos XIX e XX.

Os patrimônios históricos materiais identificados pela pesquisa incluem: Igreja de São Gervásio e Protásio, Casa de Ivanir Cancelier, Casa de Pedra Cancellier e os sobrados da família Mazzucco e Bocardo (Figura 10).

O município de Urussanga onde está inserida a APA possui uma área territorial de $254,869 \mathrm{~km}^{2}$ (IBGE, 2017). De acordo com o último censo realizado pelo IBGE em 2010, o município de Urussanga possuía 20.222 habitantes, tendo uma densidade demográfica de $79,35 \mathrm{hab} / \mathrm{km}^{2}$. Deste total, $11.404(56,39 \%)$ residem no meio urbano e $8.818(43,6 \%)$ no meio rural. Segundo o IBGE (2017), a população estimada para o município para o ano de 2017 é de 21.177 habitantes.

Como nenhuma das três comunidades (Linha Rio Maior, Rio Maior, São João do Rio Maior) tem os limites definidos e materializados geograficamente, não é possível determinar com exatidão a área exata de cada uma. Em relação à população, a Secretaria Municipal de Saúde disponibilizou os dados (Tabela 7). 


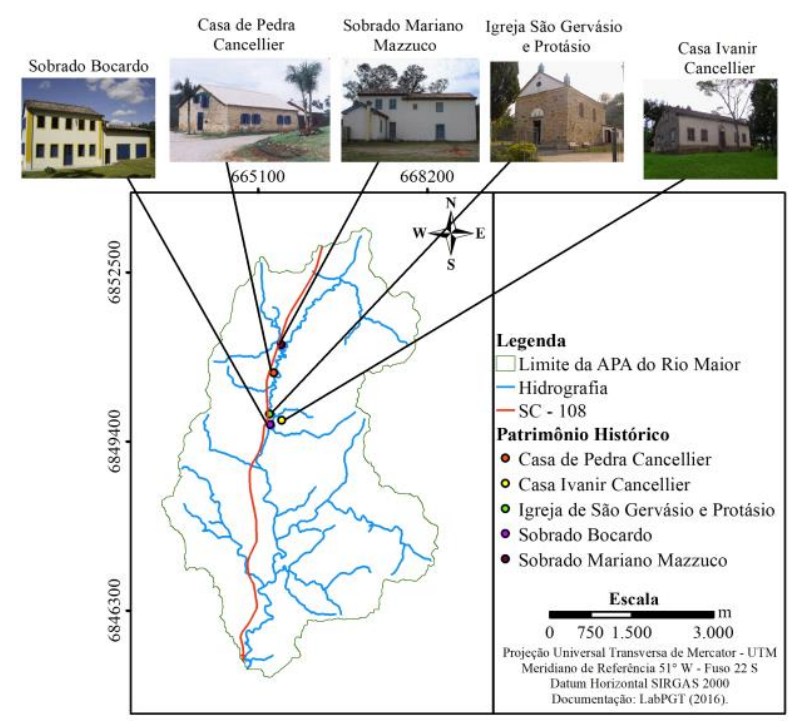

Figura 10 - Patrimônio histórico material construído da APA do Rio Maior. Fonte: autores.

Tabela 7 - População inserida na APA do Rio Maior

\begin{tabular}{|c|c|c|}
\hline Comunidade & $\begin{array}{l}\text { Linha Rio } \\
\text { Maior }\end{array}$ & $\begin{array}{l}\text { Rio Maior/ } \\
\text { São João do } \\
\text { Rio Maior }\end{array}$ \\
\hline Mulheres & 174 & 224 \\
\hline Homens & 172 & 218 \\
\hline Crianças $(<12$ anos $)$ & 50 & 45 \\
\hline Famílias & 114 & 141 \\
\hline Total & 346 & 442 \\
\hline
\end{tabular}

Fonte: Secretaria Municipal de Saúde de Urussanga, 2017.

A comunidade Linha Rio Maior conta com 314 famílias, com um total de 346 moradores, sendo $174(50,28 \%)$ mulheres e 172 $(49,71 \%)$ homens. Dentre esses, 50 (14,45\%) são crianças menores de 12 anos de idade. As comunidades, Rio Maior e São João do Rio Maior têm os seus dados agrupados na Secretária Municipal de Saúde, tendo 141 famílias com um total de 442 moradores, sendo $224(50,67 \%)$ mulheres e $218(49,32 \%)$ homens, dentre esses 50 $(11,31 \%)$ são crianças menores de 12 anos.

A estrutura fundiária tanto do estado de Santa Catarina como um todo ou do Sul Catarinense tem algumas características próprias quando comparada com o restante do Brasil. Características essas que estão ligadas ao processo de colonização que teve forte influência no século XIX no estado (Neubert; Douflot; Batista, 2000).

Como consequência do processo de colonização, há um predomínio das pequenas e médias propriedades (sistema de minifúndios), já que no sistema colonial as terras eram distribuídas às famílias em forma de pequenas propriedades (Souza; Bastos, 2011).
Tabela 8 - Distribuição do número de propriedades rurais (\%) conforme a área

\begin{tabular}{llll}
\hline Área (ha) & SC & Sul de SC & Urussanga \\
\hline Até 10 & 35,8 & 47,1 & 35,7 \\
De10 a 100 & 58,0 & 49,0 & 64,2 \\
De100 a 500 & 3,36 & 1,49 & 0,0 \\
Mais de 500 & 0,62 & 0,13 & 0,1 \\
\hline Total & 100,0 & 100,0 & 100,0 \\
\hline
\end{tabular}

Fonte: Censo Agropecuário do IBGE, 2006.

No município de Urussanga, segundo o Censo Agropecuário (2006), existiam 164 propriedades agropecuárias que ocupavam uma área de 16.655 ha. De acordo com Silva (1998) e dados levantados a campo, na zona rural do município há uma tradição de manter as propriedades que os filhos herdam dos pais. Os interlocutores das comunidades Linha Rio Maior, Rio Maior e São João do Rio Maior afirmam que ainda se mantém a tradição de passar as terras dos pais para filhos, entretanto, atualmente, alguns acabam vendendo as suas propriedades.

No município, a estrutura fundiária caracteriza-se por propriedades de 10 ha até 100 ha $(64,2 \%)$, seguido de propriedades com até 10 ha $(35,7 \%)$, ou seja, $99,9 \%$ das propriedades no município são caracterizadas por propriedades com até 100 ha.

A agricultura ocupou durante um longo período um lugar de destaque nas atividades econômicas das comunidades que estão inseridas na APA do Rio Maior. Porém, a partir da década de 1970, a agricultura entra em declínio. O recorte histórico do processo de uso e cobertura da terra em relação à agricultura será apresentado, posteriormente, no presente trabalho no item Uso e cobertura da terra.

Em relação a atividade agrícola nas três comunidades, a extensionista da Epagri (Empresa de Pesquisa Agropecuária e Extensão Rural de Santa Catarina) de Urussanga, Maria Cristina Cancellier da Costa (2017), relatou que as atividades agrícolas praticadas na comunidade são a olericultura que é realizada em duas propriedades e bananicultura e viticultura em uma propriedade. Costa ainda ressaltou que muitas propriedades apresentam o cultivo de grãos para consumo próprio e alimentação animal.

Constatou-se que apenas uma família ainda trabalha com agricultura como fonte desta renda primária na comunidade Rio Maior, sendo a olericultura, além de algumas propriedades produzem grãos para o consumo próprio e alimentação animal (Cancellier, 2017).

Segundo Cancellier (2017), na comunidade São João do Rio Maior não foi identificada pela Epagri nenhuma propriedade que 
tenha como fonte de renda a agricultura. Todavia, algumas propriedades apresentam o cultivo de grãos para consumo próprio e alimentação animal.

Vale destacar que as comunidades inseridas na APA do Rio Maior têm sua atividade bastante restrita à olericultura, fruticultura e grãos, sendo que apenas quatro famílias dependem unicamente da agricultura como forma subsistência.

Comparando essa realidade com a que Silva (1998) identificou em 1997, em que havia 66 famílias que dependiam exclusivamente da renda proveniente da agricultura, juntamente com o que foi observado a campo, é possível constar uma modificação expressiva na forma de renda primária dos moradores das comunidades que estão inseridas na APA.

$\mathrm{Na}$ pesquisa atual, somente foi identificada uma propriedade que trabalha com avicultura de corte e três propriedades que trabalham com bovinocultura de leite. A bovinocultura de corte está presente em várias propriedades como atividade secundária, é muito comum nas propriedades a criação de gado para o consumo próprio.

Na comunidade Rio Maior, existem três propriedades com apicultura. Também há criação de gado para consumo próprio (Cancellier, 2017).

Na comunidade São João do Rio Maior, existem duas propriedades que trabalham com pecuária, uma com avicultura de corte e outra com bovinocultura de leite, além da criação de gado para consumo próprio (Cancellier, 2017).

É possível constatar, por meio da pesquisa de campo e das informações fornecidas pelos funcionários da Epagri, que, de modo geral, as comunidades inseridas dentro da APA do Rio Maior têm uma pecuária pouco significativa com relação ao número de propriedades. Ainda que seja comum as propriedades criarem uma pequena quantidade de gado para o consumo familiar.

Com intuito de caracterizar as atividades econômicas da área de estudo relacionadas ao comércio, indústria e serviço, solicitou-se ao Setor de Tributos do município de Urussanga um Relatório de Econômicos em Atividade. Para melhor compreender as relações econômicas, optou-se por classificar as atividades em comercial, industrial e de serviços.

Dentro do território da APA, é possível identificar 55 empresas inseridas, sendo 16 empresas com atividade comercial, 22 com atividade industrial e 17 empresas de serviços (Tabela 9). Trinta e quatro empresas iniciaram suas atividades depois da criação da APA do Rio Maior, o que se torna preocupante, já que a APA não tem plano de manejo nem zoneamento ambiental. Quanto à localização das empresas, é possível concluir que dentro da área da APA existem dois núcleos bem estabelecidos de comércio, indústria e serviços, um ao longo da SC-108 e outro ao longo da Estrada Geral.

Tabela 9 - Panorama geral das empresas de comércio, indústria e serviços inseridas na APA do Rio Maior

\begin{tabular}{llll}
\hline Comunidade & Comércio & Industria & Serviço \\
\hline Linha Rio Maior & 7 & 8 & 9 \\
Rio Maior & 8 & 12 & 7 \\
$\begin{array}{l}\text { São João do Rio } \\
\text { Maior }\end{array}$ & 1 & 2 & 1 \\
Total & 16 & 22 & 17 \\
\hline
\end{tabular}

Fonte: Urussanga, 2017.

\section{Caracterização socioambiental da APA do Rio Maior}

Para compreender a dinâmica do uso e ocupação da terra na APA do Rio Maior, foram utilizados os anos 1957, 1978, 1996 e 2016, nos quais existem imagens temporais da área de interesse que foram usadas na interpretação conforme Tabela 10.

Percebe-se que houve uma transformação no uso e ocupação da terra. Chama atenção o aumento de área da vegetação secundária e de reflorestamento, em detrimento da diminuição da área de agricultura, que perdeu seu espaço, em média, $80 \%$ em relação ao que ocupava no ano de 1957. A agricultura desenvolvida até a década de 1980, segundo relato de produtor rural, concentrava-se no cultivo de milho, feijão e cana de açúcar e ocupava todos os espaços das propriedades, mesmo aqueles com alta declividade.

Na década de 1980, teve início a atividade de fumicultura que exigia terrenos férteis e relativamente planos. Essa prática que ocupa espaço agrícola reduzido com alta produtividade fez com que as áreas de maior declividade e menor fertilidade fossem abandonadas, sofrendo regeneração natural ou reflorestadas para servir como fonte de retirada de madeira para queima nos fornos de secagem do fumo.

Tabela 10 - Classes de uso e cobertura da Terra na APA do Rio Maior no período de 1957 até 2011

\begin{tabular}{l|l|l|l|l|l|l|l|l}
\hline & \multicolumn{7}{c}{ Área em hectares (ha) } \\
\hline & \multicolumn{2}{|c|}{$\mathbf{1 9 5 7}$} & \multicolumn{2}{c}{$\mathbf{1 9 7 8}$} & \multicolumn{2}{c}{$\mathbf{1 9 9 6}$} & \multicolumn{2}{c}{$\mathbf{2 0 1 6}$} \\
\hline & ha & $\%$ & ha & $\%$ & ha & $\%$ & ha & $\%$ \\
\hline VS & 1095 & 45 & 1557 & 64,1 & 931 & 38,3 & 1345 & $54,1 \%$ \\
\hline AG & 1039 & 42,8 & 616 & 25,4 & 85 & 3,51 & 201 & $8 \%$ \\
\hline PA & 281 & 11,6 & 240 & 9,8 & 1302 & 53,6 & 625 & $25,1 \%$ \\
\hline RF & 11 & 0,4 & 13 & 0,5 & 94, & 3,8 & 245 & $9,8 \%$ \\
\hline AM & 0 & 0 & 0 & 0 & 12,3 & 0,5 & 8 & $0,3 \%$ \\
\hline
\end{tabular}




\begin{tabular}{l|l|l|l|l|l|l|l|l}
\hline AU & 0 & 0 & 0 & 0 & 0 & 0,0 & 2 & $0,08 \%$ \\
\hline TO & 2482 & 100 & 2482 & 100 & 2482 & 100 & 2482 & 100 \\
\hline
\end{tabular}

Legenda: VS $=$ Vegetação secundária $/ \mathrm{AG}=$ Agricultura $/ \mathrm{PA}=$ Pastagem / RF $=$ Reflorestamento / AM = Atividade de mineração / $\mathrm{AU}=$ Área urbanizada $/ \mathrm{TO}=$ totais

Fonte: Dados dos anos de 1957, 1978 e 1996 (SILVA, 1998) e 2016 (LabPGT, 2016).

A classe de vegetação secundária, que no ano de 1957 ocupava 45\% da área, passou a ocupar $64 \%$ no ano de 1978. Atualmente, está se reduzindo aos índices do ano de 1957 na sua extensão espacial. Observa-se na vegetação secundária a presença de espécies invasoras que acontece devido à disseminação natural das cultivares do reflorestamento com predominância dos gêneros Eucalyptus, Acácia e Pinus.
Na Figura 11, pode-se observar, no ano de 2016, que parte da bacia já estava urbanizada, e a tendência é de que o espaço ao longo da rodovia SC-108 que liga Orleans - Criciúma no trecho de Urussanga sofra uma ocupação cada vez mais acelerada de estabelecimentos comerciais, devido ao fluxo intenso de veículos circulando.

Pode-se avaliar, na Figura 11, que a ocupação da APA do Rio Maior evoluiu em se tratando de qualidade ambiental, porque até o ano de 1978 as atividades de fumicultura, juntamente com milho e feijão, que exigem uma carga de insumos na sua produção, eram a base da economia dos produtores rurais.

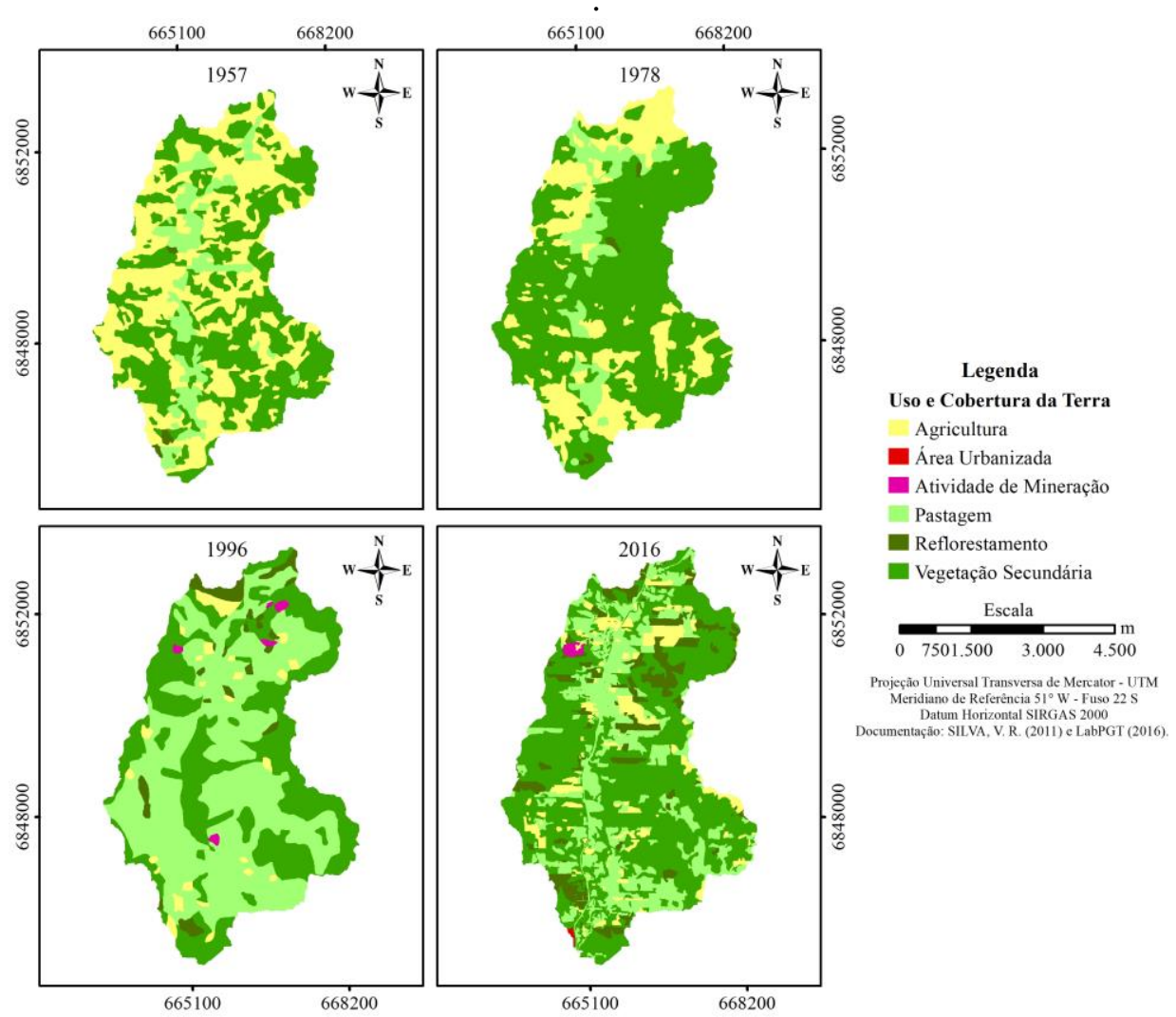

Figura 11 - Uso e cobertura da terra na APA do Rio Maior em 1957, 1978, 1996 e 2011. Fonte: autores..

Os principais impactos ambientais identificados na APA do Rio Maior na pesquisa de campo foram: descarte incorreto de resíduo sólido, poluição atmosférica e sonora, poluição e assoreamento do curso hídrico, lago artificial para irrigação, redução da vazão de alguns contribuintes do rio Maior e usos inadequados na área de preservação permanente (APP) dos cursos hídricos e das nascentes. Vale ressaltar a importância de um estudo mais detalhado dos impactos ambientais na APA, uma vez que esse pode vir a servir de base para ações de preservação.
Os impactos identificados corroboram com os apontados nos trabalhos elaborados por Nascimento e Burtsztyn (2012), Comitê da Bacia Hidrográfica do rio Urussanga (2015) e Ladwig et al. (2017). No trabalho conduzido por Nascimento e Burtzstyn (2012), os impactos estão relacionados às atividades de mineração que acontecem na APA. Segundo Ladwig et al. (2017), os impactos estão relacionados à questão da ocupação desordenada das margens do rio e das nascentes.

Em campo, foi possível identificar alguns dos impactos já citados em outros trabalhos, assim 
como novos impactos ambientais (figura 12). A situação mais preocupante está relacionada aos impactos provenientes da atividade de mineração e da ocupação irregular nas APPs.

Em relação à atividade mineração, ACRIMA (Associação dos Moradores do Rio Maior) vem manifestando a sua preocupação há cerca de 10 anos, enviando cartas e solicitações a FATMA (Fundação de Amparo à Tecnologia e Meio Ambiente), movendo uma Ação Civil Pública, promovendo e organizando reuniões e articulações com a sociedade local. Porém, ela vem sofrendo com o desgaste e troca de diretoria, não pautando mais com tanta regularidade a questão dos impactos provenientes da mineração.

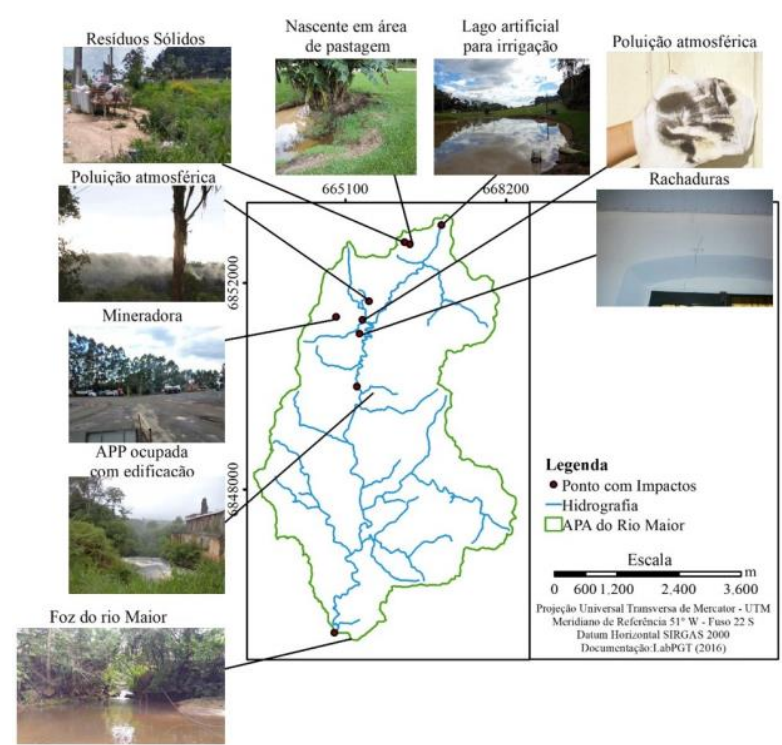

Figura 12 - Mapa de localização dos impactos identificados na pesquisa de campo. Fonte: autores.

Em relação aos impactos identificados nas APPs, Sutil et al. (2017) desenvolveram no âmbito do Laboratório de Planejamento e Gestão Territorial (LabPGT) um trabalho visando determinar áreas prioritárias para restauração da mata ciliar na APA do Rio Maior. Os resultados finais obtidos pelo trabalho demonstram uma preocupação em relação à qualidade ambiental da APA, uma vez que cerca de 300 ha tem alta prioridade de recuperação da mata ciliar $(36,7 \%)$. Cruzando o mapa de uso e cobertura da terra e das áreas prioritárias, identificou-se que as áreas prioritárias para recuperação são predominantes na classe pastagem seguido da classe agricultura (Sutil et al., 2017).

\section{Conclusões}

Em relação à caracterização dos aspectos físicos da APA, vale destacar que as técnicas de geoprocessamento possibilitaram elaborar os mapas temáticos associativos e específicos necessários para dar suporte ao início da elaboração futura do plano de manejo. Em relação a cartografia produzida é preciso melhorar a escala de uns alguns dados trabalhados, porém é também de conhecimento que no Brasil se tem uma escassez de dados no que tange algumas temáticas especificas.

No que se refere aos aspectos socioeconômicos que foram levantados por meio da pesquisa bibliográfica, documental e de campo, é necessário um aprofundamento em relação à estrutura fundiária, meios de produção e à população que reside nas três comunidades.

$$
\text { Com relação aos aspectos }
$$

socioambientais, foi realizada uma análise temporal do uso e cobertura da terra para compreender como se deu a ocupação no território da APA, além de levantar os principais impactos ambientais identificados na APA. Em relação aos impactos ambientais, é necessário um estudo com maior profundidade a fim de caracterizar de forma mais ampla os mesmos, uma vez que essa informação será de grande importância para elaboração do plano de manejo.

\section{Agradecimentos}

À Coordenação de Aperfeiçoamento de Pessoal de Nível Superior - CAPES e à Fundação de Amparo à Pesquisa e Inovação do Estado de Santa Catarina - FAPESC.

\section{Referências}

Adami, R. M.; Cunha, Y. M. 2014. Caderno do educador ambiental das bacias dos rios Araranguá e Urussanga. Blumenau: Fundação Agência da Água do Vale do Itajaí, 137p

Back, A. J. et al. 2016. Características morfométricas da bacia hidrográfica relacionadas à erosão hídrica. In: POLETO, C. (Org.). Hidrossedimentologia. Rio de Janeiro: Editora Interciência 1, 10-30.

Bailly, D.; Fernandes, C. A.; Silva, V. F. B.; Kashiwaqui, E. A. L.; Damásio, J. F.; Wolf, M. J.; Rodrigues, M. C. 2012. Diagnóstico ambiental e impactos sobre a vegetação ciliar da microbacia do córrego da ponte, área de proteção ambiental do rio Iguatemi, MS. Revista em Agronegócios e Meio Ambiente, Maringá 2, 1-19.

Baldessar, Q. D. 2005. Imigrantes: sua história, costumes e tradições no processo de colonização no Sul do estado de Santa Catarina. 2. ed. [S. 1.]: Do autor, 315 p.

Baldin, N. 1999. Tão fortes quanto à vontade: história da imigração italiana no Brasil: os 
vênetos em Santa Catarina. Florianópolis: Insular, $279 \mathrm{p}$.

BRASIL. 2009. Justiça Federal. $1^{\text {a }}$ Vara Federal de Criciúma, SC. Processo $\mathrm{n}^{\circ}$ 2000.72.04.002543-9. Autor: Ministério Público Federal. Réu: Nova Próspera Mineração S.A. e outros. Recuperação dos passivos ambientais decorrentes da mineração de carvão no sul do Estado de Santa Catarina. Terceiro relatório de monitoramento dos indicadores ambientais. Criciúma, set. 256 p.

Cancellier. M. C. 2017. Entrevista concedida a Thaise Sutil. Urussanga, 27 out.

Cômite da Bacia Hidrográfica do Rio Urussanga (Urussanga). 2015. Área de proteção ambiental do Rio Maior. Urussanga: Slide, 37 slides, color.

Dufloth, H. J.; Cortina, N. Veiga; M. Da Mior, L.C. (org). 2005. Estudos básicos regionais de Santa Catarina. EPAGRI, Florianópolis, Brasil , 1 CD-Rom.

EMBRAPA. 2014. Serviço de Produção de Informação. Sistema brasileiro de classificação de solos. 4. ed Brasília, DF: EMBRAPA, 376 p.

EMBRAPA. 1979. Solos do Estado de Santa Catarina. Rio de Janeiro, 726p. (Boletim de pesquisa e desenvolvimento, 46).

Escaravaco, Arnaldo. Urussanga. 1984. As Imagens da História da Colonização à última década do século XIX. Criciúma: [s.n.], v.1.

Ferri, G. K. 2017. A colonização italiana em Urussanga, SC: a trajetória da família de Bona Sartor. Universidade Federal da Fronteira Sul UFFS. Chapecó, SC, jul.

Gil, A. C. 1999. Métodos e técnicas de pesquisa social. 5. ed. São Paulo: Atlas, 207p.

Horton, R. E. 1945. Erosional Development of Streams and their Drainage Basins; Hydrophysical Approach to Quantitative Morphology. Geological Society of America Bulletin, v. 56, n. 3, p.275-370.

IBGE - Instituto Brasileiro de Geografia e Estatística. 1992. Manual técnico da vegetação brasileira. Rio de Janeiro, 92p. (Manuais Técnicos em Geociências, 1).

IBGE. 2017. Diretoria de Pesquisas, Coordenação de População e Indicadores Sociais, Estimativas da população residente com data de referência.

IBGE. 2009. Coordenação de Recursos Naturais e Estudos Ambientais. Manual Técnico de geomorfologia. 2. ed. Rio de Janeiro, RJ: IBGE.

Klein, R. M. 1978. Mapa fitogeográfico do estado de Santa Catarina. Herbário Barbosa Rodrigues, Itajaí: UFSC, 24p.
Ladwig N. I.; Zocche, J J.; Amaro, A G.; Scussel, C. 2017. Impactos ambientais na área de proteção ambiental do Rio Maior, no município de Urussanga/SC. In: Ladwig, N, I.; Schwalm, H. (Org.). Planejamento e gestão territorial: gestão integrada do território. Criciúma: UNESC, p.79-87.

Lavina, R. 1994. Os Xokleng de Santa Catarina: uma etnohistória e sugestões para os arqueólogos, São Leopoldo: UNISINOS.

Maack, R. 2001. Breves Notícias Sobre a Geologia dos Estados do Paraná e Santa Catarina. Brazilian Archives Of Biology And Technology, [s.1.], 2. p.169-288, dez. FapUNIFESP.

Marconi, M. de A.; Lakatos, E. M. 2010. Fundamentos de metodologia científica. 7. ed. São Paulo: Atlas,. 297 p.

Ministério Público Federal (MPF). Procuradoria da República do Município de Criciúma. Ministério Público Federal. Recomendação $n^{\circ}$ 21 /2010. 2010. Darlan Airton Dias. Disponível em: <www.mpf.mp.br/atuacaotematica/ccr4/dados-da.../recomendacao_212010.../file>. Acesso em: 17 nov. 2017.

Moura, A. C. M. 2014. Geoprocessamento na Gestão e Planejamento Urbano. 3. ed. Rio de Janeiro: Interciência, 312p.

Nascimento, D. T.; Bursztyn, Ma. A. A. 2012. Análise de conflitos socioambientais: o caso da comunidade rural de Rio Maior, município de Urussanga, Santa Catarina. Revista Internacional Interdisciplinar Interthesis, [s.1.], 9, 1-34, 17 dez.Universidade Federal de Santa Catarina (UFSC).

Neubert, E. O.; Duflot, J. H.; Batista, K. M. 2000. Evolução da estrutura fundiária e da ocupação das terras do Litoral Sul Catarinense. Revista de Ciências Humanas (Criciúma), UNESC, Criciúma 6, 37-48.

Orlandi Filho, V.; Krebs, A. S. J.; Giffoni, L. E. 2006. Coluna White, Serra do Rio do Rastro, SC - Seção Geológica Clássica do Continente Gonduana no Brasil. In: Winge, M.; Schobbenhaus, $\quad$ C.; $\quad$ Berbert-Born,M.; Queiroz,E.T.; Campos,D.A.; Souza,C.R.G.; Fernandes,A.C.S. (Edit.) Sítios Geológicos e Paleontológicos do Brasil.

Pereira, J. R. 2016. Caracterização hidrológica como ferramenta de análise ambiental da APA do Rio Maior. 103 f. Dissertação (Mestrado) Programa de Pós-graduação em Ciências Ambientais, Universidade do Extremo Sul Catarinense, Criciúma, 2016.

Silva, L. A. P. 2011. Caracterização Mecânico do Carvão da Formação Rio Bonito, Camada Barro Branco - SC. 232 f. Dissertação 
(Mestrado) - Curso de Programa de Pósgraduação em Engenharia Civil, Puc- Rio, Rio de Janeiro, 2011.

Silva, L. C. 1987. Geologia do Pré-Cambriano / Eopaleozóico de Santa Catarina. In: Textos básicos de Geologia e Recursos Minerais de Santa Catarina. Florianópolis: DNPM, Secretaria da Ciência e Tecnologia, Minas e Energia, n.1.

Silva, V. R. 2010. Aspectos da vegetação da bacia do rio Maior no município de Urussanga SC. XVI Encontro Nacional dos Geógrafos: Crise, práxis, autonomia: espaços de resistência e de esperanças, Porto Alegre, p.110 , jul.

Silva, V. R. 1998. Caracterização física e sócioeconômica da microbacia do rio Maior, Urussanga - SC. 1998. 103 f. Tese (Doutorado) - Curso de Curso de Mestrado em Geografia, Departamento de Geociências, Universidade Federal de Santa Catarina, Florianópolis.

Souza, J. J.; Bastos, M. N. 2011. A Formação Socioespacial do Estado De Santa Catarina, Brasil. Revista Geográfica de América Central, Costa Rica 4, 1-14.

Strahler, A. N. 1957. Quantitative analyses of watershed geomorphology. Transactions of American Geophysical Union, Washington, DC, v. 38, p. 913-920.
Sutil, T.; Gonçalves, F. N.; Ladwig, N. I.; De Conto, D.; Cury, M. D. 2017. Determinação de áreas prioritárias para restauração da mata ciliar na microbacia do rio Maior Urussanga/SC. In: II Congresso de engenharia ambiental do sul do brasil, 2., 2017, Lages. Anais volume 1. Lages: Editora Udesc, $1,50-60$.

Tomasi, J. M. 2012. Ritornando a lleorigini: a identidade italiana em Urussanga (SC) no final do século XX e início do XXI. Florianópolis: Revista Catarinense de História.

Trein, H. A. 2008. A implicação antrópica na qualidade dos recursos hídricos subterrâneos da bacia hidrográfica do rio Urussanga - SC. 149 f. Tese (Doutorado) - Curso de Pósgraduação em Geociências e Meio Ambiente, Universidade Estadual Paulista, Rio Claro, 2008.

Urussanga (Município). Constituição (1998). Lei $n^{\circ} 1.665$, de 27 de novembro de 1998. Cria área de Proteção Ambiental do Rio Maior e Dá Outras Providências. 1. Ed.

Viero, A. C.; Silva, D. R. da A. 2016. Geodiversidade do estado de Santa Catarina. Porto Alegre: CPRM, $160 \mathrm{p}$.

Villela, S. M.; Mattos, A. 1975. A Hidrologia Aplicada. Mc Graw-Hi ed. São Paulo: Villela, Swami Marcondes; Mattos, Arthur,. p. 245. 